DOI: 10.17707/AgricultForest.62.1.10

\author{
Miroslav ČIZMOVIĆ, Ranko POPOVIĆ, \\ Mirjana ADAKALIĆ, Biljana LAZOVIĆ, Tatjana PEROVIĆ
}

\title{
CHARACTERISTICS OF FLOWERING AND FRUIT SET OF MAIN POMEGRANATE VARIETIES (Punica granatum L.) IN MONTENEGRO
}

\section{SUMMARY}

Morphological characteristics of flowers and flowering were studied in three main pomegranate varieties grown in Montenegro: 'Slatki barski', 'Šerbetaš' and 'Dividiš meke kore'. The varieties grown in three different locations: Dobra Voda and Tomba in the Bar coastal area, and in Golubovci area near Podgorica, were represented with five trees per locality. Results on dynamics of forming and falling of flowers and fruits are presented in the paper. The maximum length and width of a flowers in all varieties was at hermaphroditic type of flower $(4.75 \mathrm{~cm})$, a statistically significantly higher compared to the other two categories examined. Hermaphroditic type of flower has a statistically significantly longer pestle $(13.58 \mathrm{~mm})$, while the shortest in functionally male-type $3.93 \mathrm{~mm}$. There was a highly significant correlation between the length of the pistil and diameter of a flower $(\mathrm{r}=0.8022 * *)$, as well as the length of the flower $(\mathrm{r}=0.7042 * *)$. Functionally male type of flower had in average the highest number of stamens (320), which is in the function of production of a sufficient amount of pollen and better fertilization, and the lowest was registered in hermaphrodite flower type (272). Pomegranate flowering lasted from two to almost three months in the cultivars 'Šerbetaš' and 'Slatki barski' from Dobra Voda in 2004 and 2003 respectively. The highest number of flowers per fruiting shoot was in variety 'Dividiš meke kore' (36.1) at locality Balabani in 2002. The lowest number of flowers (8.25) was formed in 'Šerbetaš' variety in 2004. Flowering maximum in the varieties grown in localities Tomba and Balabani was in the first half of June, while in Dobra Voda delayed in average 7-10 days, due to the climatic conditions in the orchard located at higher altitude.

Keywords: pomegranate, Punica granatum $L$, flowering, falling of fruits

\section{INTRODUCTION}

Pomegranate is considered one of the longest grown fruit species in the area with influence of the Mediterranean climate in Montenegro. Richness of pomegranate wild forms confirms that this area is one of gene-centers of this fruit species (Zohary and Hopf, 2000). Pomegranate blossoming depends on the agro-

\footnotetext{
1 Miroslav Čizmović, Ranko Popović, Mirjana Adakalić, Biljana Lazović, Tatjana Perović, (corresponding author: miroslaw@t-com.me), Biotechnical Faculty, University of Montenegro, MONTENEGRO

Paper presented at the $6^{\text {th }}$ International Scientific Agricultural Symposium "AGROSYM 2015".

Notes: The authors declare that they have no conflicts of interest. Authorship Form signed online.
} 
ecological conditions and lasts long, from March-April to June-August (Mars 2000). Pomegranate flower has a corolla intense red color, formed as single or in groups of 5-7 (Melgarejo, 1996). Number of stamens ranges from 200 to 350, and in complete flowers has 400 -1000 ovules (Derin and Eth, 2001). Blossoming takes place into two to four waves, with the best quality fruits originate from hermaphrodite flowers that are formed in the first flowering period (Mars, 2000; Buljko, 1974). Pomegranate forms, according to numerous authors, two types of flowers: type A- male flower with ovary that contains only a few ovules, and type B - hermaphrodite flower only that can bear fruit. Nalawadi et al. (1973), by examining pomegranate flower recognize three types of flowers: small, intermediate and hermaphrodite.

The objective of this study is to investigate the floral morphology, and dynamics of formation and falling of flowers and fruits in three most important pomegranate varieties grown in Montenegro.

\section{MATERIAL AND METHODS}

The study was conducted on three prevalent pomegranate varieties in Montenegro: 'Slatki barski', 'Šerbetaš' and 'Dividiš meke kore' grown on three different locations. Localities Dobra Voda (DV) and Tomba (MN) are situated in Bar municipality in the coastal region, and Balabani near Golubovci (ZP) in Zeta-Bjelopavlici valley. Orchards in Dobra Voda are situated in the highest altitude (294 m). 'Slatki barski' variety is presented on each location, 'Šerbetaš' in Dobra voda and Tomba, while 'Dividiš meke kore' is grown only in Balabani village. Each of the varieties was presented with 5 shrubs per locality, and all shrubs were of the same age (13 and 14 years) and in the full productive period.

The study of the dynamics of developing, flower and fruitslets fall was followed on 5 randomly selected bearing branches per tree, recording changes every seven days until the moment of harvest. Anatomy features of flower were analyzed on a sample of 20 flowers per tree, where the flowers were divided into three groups: small, intermediate and hermaphrodite, according the length of the pistil and the ovary development. The flowers for analysis were taken in E3 advanced of F initial stage (Melgarejo et al., 1997). Statistical analysis of the observed flower characteristics was done by analysis of variance and the differences were compared by Takey test for the level of significance 95 and $99 \%$, and by the Pearson's correlation analysis.

\section{RESULTS AND DISCUSSION}

A In the observed years, similarities in the dynamics of the formation of flowers (Figures 1-3) are notable. Pomegranate flowering is the phenological phase that lasts long and in the tested localities usually occurs in one or two large waves.

The earliest formation of flowers was recorded in 2002 (26 April) on localities Tomba and Balabani. The first maximum of flowering in these locations was recorded in the period from 10-25 May in varieties 'Slatki barski' 
and 'Dividiš meke kore', while the second maximum was on 9 June. Variety 'Dividiš meke kore' had earlier picks, and in average formed the highest number of flowers. The lowest number of flowers formed variety 'Šerbetaš' in the site Tomba, but more presented hermaphroditic type. Certain discrepancies were registered in 2003, the year with somewhat different climate conditions. This is mostly related to the temperature, as ecological factor that has the greatest impact on the flowering (Adhikari and Adhikari, 2010). Flowering in 2003 was delayed due to lower air temperature in the period 6-9 April and slightly colder March. Very high temperatures in May compensated this delay in the later period of flowering. In 2003 it was registered one maximum for the studied cultivars; 25 May for the varieties on localities Tomba and Balabani, and 21 June on the locality Dobra Voda. In this year, there were much less formed flowers compared to other two years. The formation of flowers in 2004 had one maximum, 31 May for the varieties grown in Balabani and Tomba, and 13 June for the varieties in Dobra Voda. It is evident that flowering is delayed for two weeks in Dobra Voda, due to climatic conditions of the orchard which is at higher altitude.

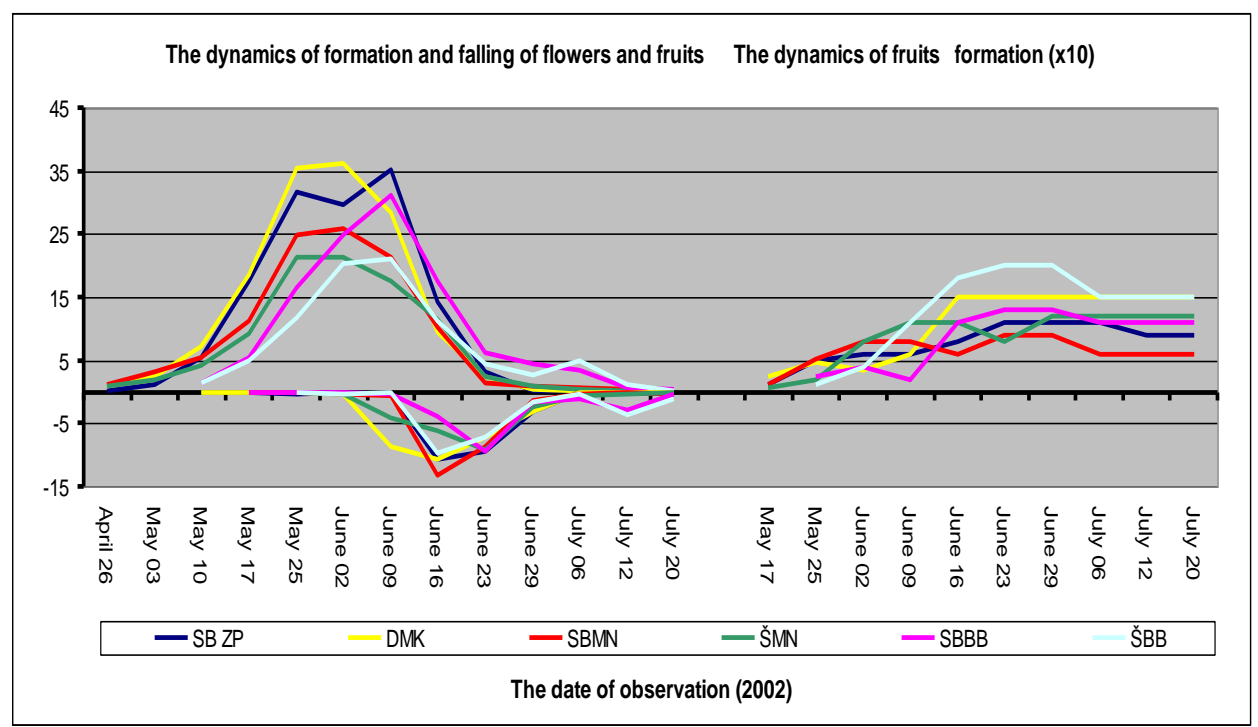

Graph.1. The dynamics of formation and falling of flowers and fruits, and fruits formation (2004)

The fall of flowers in average begins two weeks compared to their formation. Though, the maximum fall of flowers occurs later than the flowering maximum 14-17 days. This is consistent with the duration of the blooms stated by malgarejo et al., (1997). Falling of male flowers is a normal phenomenon, because the process of fertilization is completed. In addition to these also falls part of perfect flowers and formed fruitlets. Formation of fruits was registered early in 2002 (17 may) in cultivars grown in localities balabani and tomba and the latest in variety šebetaš in localities tomba and dobra voda (13 june 2004). 
Formed fruits cease to fall by 24 july in average, and mature by the end of autumn. In average, the largest number of formed fruits per shoot was registered in variety 'šerbetaš' (1.5), which had a smaller number of flowers, but hermaphrodite in higher percentage.

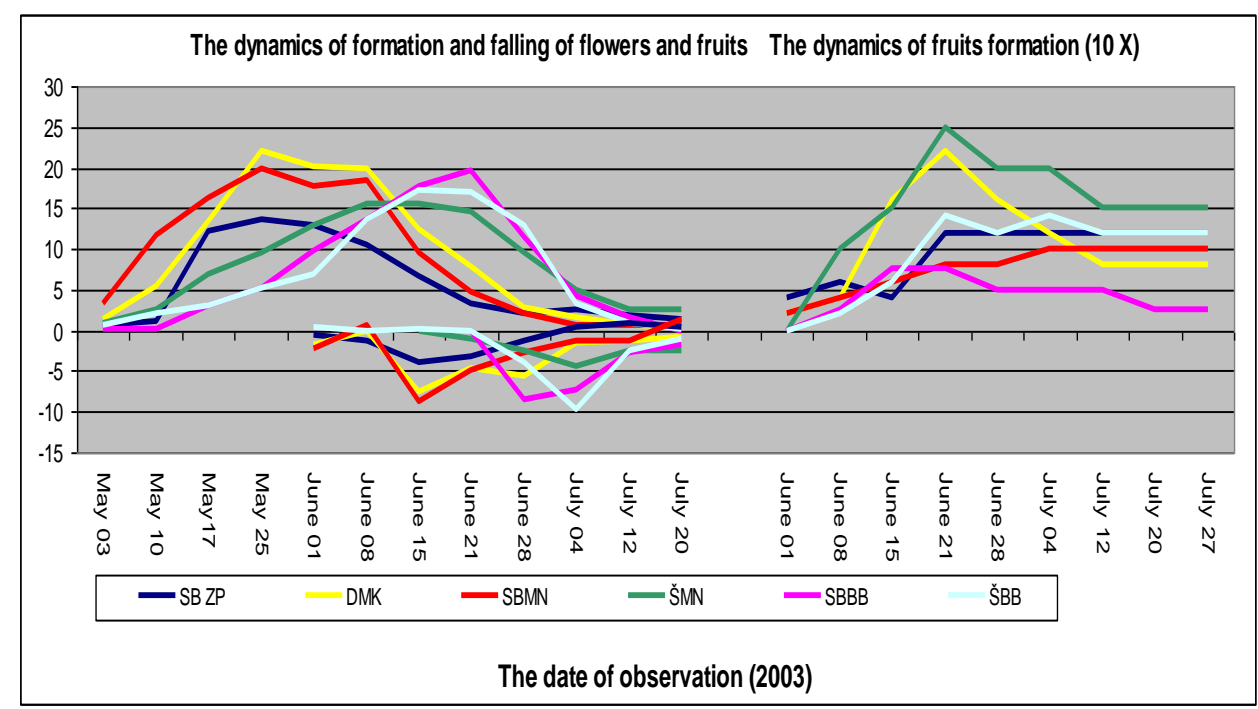

Graph.2. The dynamics of formation and falling of flowers and fruits, and fruits formation (2003)

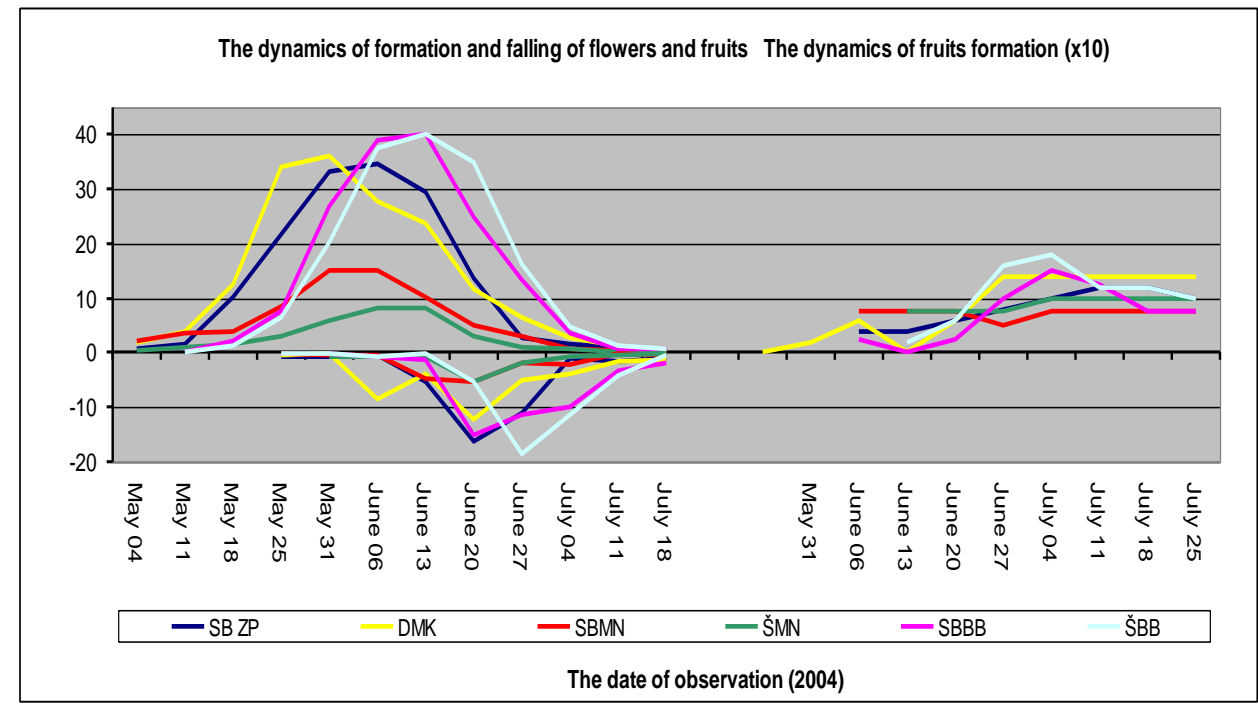

Graph.1. The dynamics of formation and falling of flowers and fruits, and fruits formation (2004)

The ratio of male and perfect flowers was studied by gozlecki and kaynak (2000) in the known turkish variety hicaznar. It was found variability in the 
ration of hermaphroditic and male flowers, stating that perfect flowers were represented within 13.58 to $22.32 \%$. Wetzstein et al., (2011) reported that in pomegranate changes periodically the ratio of male and hermaphroditic flowers, conditioned by environmental factors, age of the plant, which is an evolutionary advantage of pomegranate

Table 1. Floral morphology, comparison of differences

\begin{tabular}{|c|c|c|c|c|c|c|c|c|c|c|c|c|c|c|c|c|c|c|}
\hline \multirow{2}{*}{\begin{tabular}{|c|}
$\begin{array}{c}\text { Variety/ } \\
\text { treatment }\end{array}$ \\
Type of flower
\end{tabular}} & \multicolumn{3}{|c|}{$\begin{array}{l}\text { Length of flower } \\
(\mathrm{cm})\end{array}$} & \multicolumn{3}{|c|}{$\begin{array}{l}\text { Diameter of } \\
\text { flower }(\mathrm{cm})\end{array}$} & \multicolumn{3}{|c|}{ No of petals } & \multicolumn{3}{|c|}{ No of sepals } & \multicolumn{3}{|c|}{$\begin{array}{l}\text { Length of pistils } \\
\text { (mm) }\end{array}$} & \multicolumn{3}{|c|}{ No of stamens } \\
\hline & M & I & $\mathrm{H}$ & M & I & $\mathrm{H}$ & M & I & $\mathrm{H}$ & M & I & $\mathrm{H}$ & M & I & $\mathrm{H}$ & M & I & $\mathrm{H}$ \\
\hline Slatki barski DV & 4.12 & 4.33 & 4.89 & 1.01 & 1.13 & 1.38 & 7,53 & 7.50 & 7.73 & 7.19 & 7.33 & 7.70 & 3.81 & 7.83 & 12.68 & 376.67 & 327.56 & 348.67 \\
\hline Slatki barski MN & 3.84 & 4.19 & 4.73 & 0.95 & 1.12 & 1.47 & 7.37 & 8.25 & 6.67 & 7.18 & \begin{tabular}{|l|}
8.12 \\
\end{tabular} & 6.67 & 3.17 & 6.62 & 12.67 & 341.59 & 246.00 & 333.38 \\
\hline \begin{tabular}{|l} 
Slatki barski ZP \\
\end{tabular} & 3.69 & 3.96 & 4.71 & 0.90 & 1.04 & 1.46 & 6.73 & 7.35 & 6.83 & 6.59 & 7.01 & 6.75 & 4.25 & 7.71 & 13.22 & 273.81 & 241.19 & 305.03 \\
\hline Šerbetaš DV & 4.11 & 4.35 & 5.10 & 1.05 & 1.15 & 1.69 & 8.33 & 8.21 & 7.61 & 7.03 & 7.97 & 7.45 & 3.44 & 7.94 & 14.84 & 381.39 & 315.78 & 360.48 \\
\hline Šerbetaš ZP & 3.92 & 4.12 & 4.51 & 0.92 & 1.01 & 1.45 & 7.05 & 7.24 & 6.412 & 6.94 & 6.14 & 6.92 & 4.94 & 7.61 & 14.40 & 264.88 & 250.52 & 233.06 \\
\hline Divivdiš meke kore & 3.95 & 4.32 & 4.53 & 1.00 & 1.18 & 1.40 & 7.06 & 7.33 & 6.53 & 6.71 & 7.33 & 6.37 & 3.94 & 8.33 & 13.58 & 282.22 & 256.02 & 299.17 \\
\hline Average & $3.94 \mathrm{~b}$ & $4.21 \mathrm{~b}$ & $4.75 a$ & $0.97 \mathrm{~b}$ & $1.10 \mathrm{~b}$ & $1.47 \mathrm{a}$ & $7.35 \mathrm{a}$ & $7.51 \mathrm{a}$ & $7.10 \mathrm{a}$ & $6.94 a$ & $7.32 \mathrm{a}$ & $6.97 \mathrm{a}$ & $3.93 \mathrm{c}$ & $7.67 \mathrm{~b}$ & $13.57 \mathrm{a}$ & 320.102 & 313.30ab & 272.841 \\
\hline $\mathrm{HSD}_{0,05}$ & & 0.3410 & & & 0.1397 & & & 0.632 & & & 0.5838 & & & 1.257 & & & 46.144 & \\
\hline HSD $_{0,01}$ & & 0.4346 & & & 0.1780 & & & 0.805 & & & 0.7441 & & & 1.602 & & & 58.811 & \\
\hline Legend & & & & & le flow & ters, & & ermed & iate flo & wers, & $\mathbf{H}-\mathbf{l}$ & & froditi & c $(\mathrm{com}$ & & flowers & & \\
\hline
\end{tabular}

According to the results presented in table 1, hermaphrodite type of flower has a significantly longer and wider flower in relation to male and intermediate type of flower. This is the result of much larger ovary and longer pistil. Mars (2000) describes the male type of flower as a "bell-shaped", while the hermaphrodite as "vase-shaped". According to wetzstein et al. (2011), "male" flower of 'wonderful' variety was $2.7 \mathrm{~cm}$ long, and hermaphrodite $3.6 \mathrm{~cm}$.

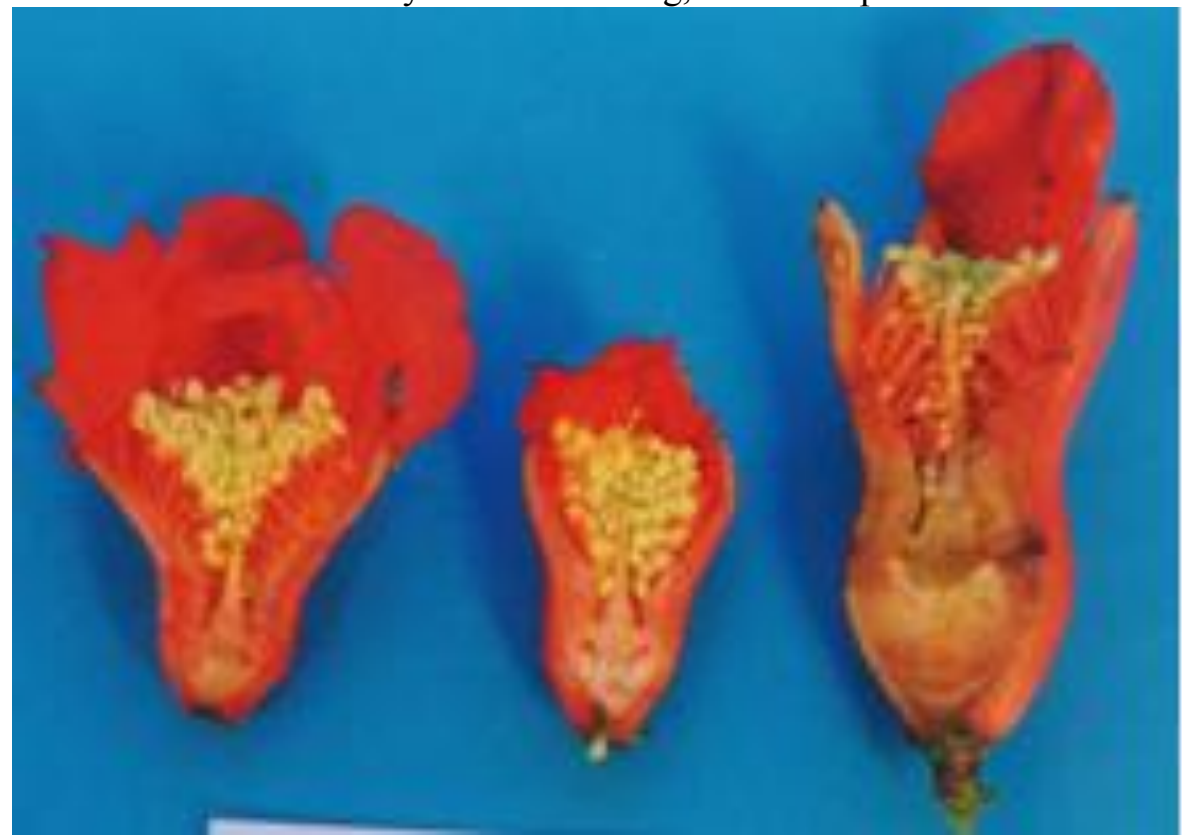

Figure 1. "Male", intermediate and hermaprodite tipe of flowers 


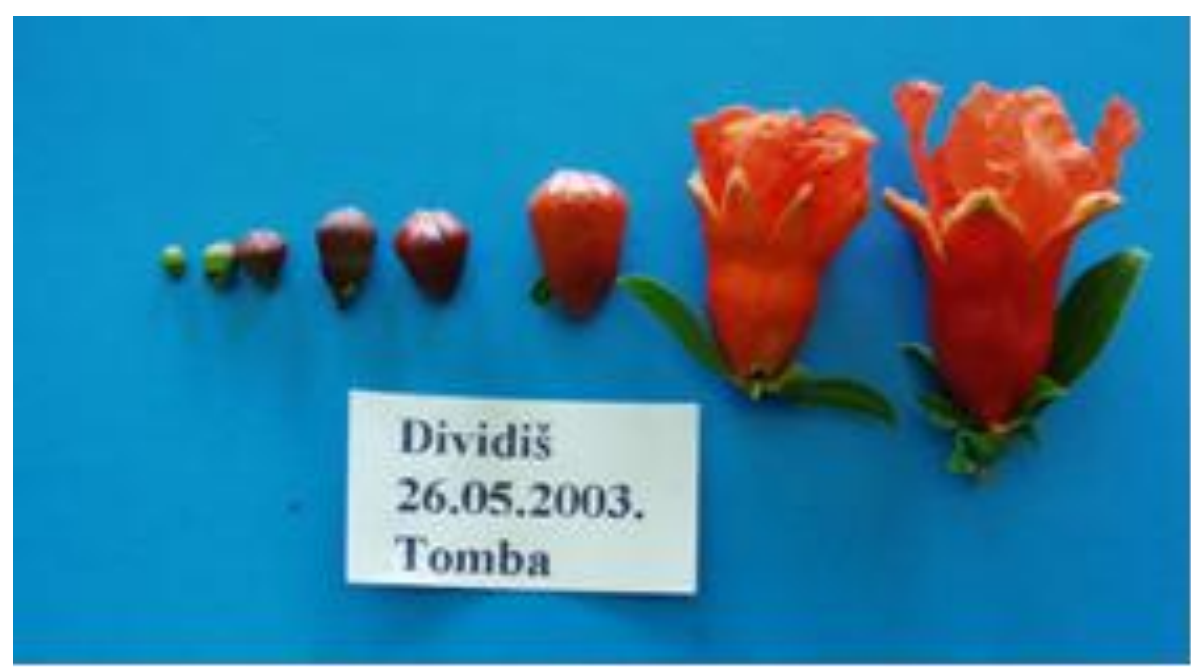

Figure 2. Different stage of develeopm pomegranate type of flowers

According to martinez et al. (2000), in three studied clones the length and width of flower varied, although the authors point out that flowers were taken from the orchard only 4 years old. Calyx and petal number approximately is of the same values indicated by martinez et al. (2000). According to the correlation analysis these two features of flowers are statistically significantly conditioned (table 2$)$, and as indicated by the coefficient of determination $(\mathrm{r} 2=0.4943)$ they determine each other with $50 \%$.

Table 2. Correlation matrix of floral morphology

\begin{tabular}{|c|c|c|c|c|c|}
\hline & $\begin{array}{l}\text { Lengt of } \\
\text { flowers }\end{array}$ & $\begin{array}{c}\text { Diameter of } \\
\text { flowers }\end{array}$ & No of petals & No of sepals & $\begin{array}{l}\text { Lenght of } \\
\text { pistil }\end{array}$ \\
\hline \multirow{2}{*}{$\begin{array}{l}\text { Diameter of } \\
\text { flowers }\end{array}$} & $\mathrm{r}=0.7031 * *$ & & & & \\
\hline & $r^{2}=0.4943$ & & & & \\
\hline No of petals & $\mathrm{r}=0.7116^{\mathrm{ns}}$ & $\mathrm{r}=0.0916^{\mathrm{ns}}$ & & & \\
\hline \multirow[b]{2}{*}{ No of sepals } & & & & & \\
\hline & $\mathrm{r}=0.2170^{\mathrm{Is}}$ & $\mathrm{r}=0.1462^{\mathrm{Is}}$ & $\frac{r=0.8785^{* *}}{r^{2}=0.7718}$ & & \\
\hline \multirow{2}{*}{$\begin{array}{l}\text { Lenght of } \\
\text { pistil }\end{array}$} & $\mathrm{r}=0.5549 * *$ & $\mathrm{r}=0.8022 * *$ & $\mathrm{r}=-0.1024^{\mathrm{ns}}$ & $\mathrm{r}=-0.0300^{\mathrm{ns}}$ & \\
\hline & $\mathrm{r}^{2}=0.3079$ & $r^{2}=0.6435$ & & & \\
\hline \multirow{2}{*}{$\begin{array}{c}\text { No of } \\
\text { stamens }\end{array}$} & $\mathrm{r}=-0.1534^{\mathrm{ns}}$ & $\mathrm{r}=0.1111^{\mathrm{ns}}$ & $\mathrm{r}=0.6461 * *$ & $\mathrm{r}=0.6498 * *$ & $\mathrm{r}=-0.3153^{\mathrm{ns}}$ \\
\hline & & & $r^{2}=0.4174$ & $r^{2}=0.4224$ & \\
\hline
\end{tabular}

* Results are significant at $\mathrm{p} \leq 0.05$ and 0.01

Hermaphrodite type of flower has a significantly longer pistil in relation to the other two types of flowers. Pistil length is in statistically significant correlation to the length of the flower $(r=0.5549)$, particularly in relation to the width of the flower $(r=0.5549)$. Length of pistil is, according to the coefficient of determination, determined with $64 \%$ by the width of a flower. The largest 
number of stamens was registered within male flower (320.10), significantly more than in hermaphrodite flower. Number of stamens is in statistically significant correlative dependence to the number of sepals and petals.

Examined cultivars did not show statistically significant differences in the flower structure; therefore, these features could not be used to determine and to distinguish varieties.

\section{CONCLUSIONS}

Blossoming of pomegranate in conditions of montenegro occurs in one or two large waves. The most important factor influencing the dynamics of flowers formation is outside temperature.

The rapid flowering always occurs two weeks earlier in the localities tomba and balabani, while in the orchard at higher altitude was delayed for two weeks. The maximum fall of flowers and fruitlets happens 14 to 17 days in relation to the maximum of flower formation. Fall of formed fruitlets stops in the period 20-25 july.

Hermaphrodite flowers are larger in length and width, with a long pistil, which is a correlatively conditioned characteristic. Male flowers have significantly more stamens compared to the hermaphroditic flowers, which is in function of better fertilization.

\section{REFERENCES}

Adhikari, S., Adhikari, K.M. (2010): Floral Phenology and pollination ecology of Punica granatum L. in Kathmandu, Nepal, Nepal journal of Sciemce and Technology, 11., pg. 115-124, Nepal.

Buljko, M. (1985): Flower and fruit drop in pomegranate as the cause of its non-bearing. Čačak, Yugoslav pomology, 19, 447- 452.

Derin, K., Eti, S. (2001): Determination of pollen quality, quantity and effect of cross pollination on the fruit set and quality in the pomegranate, Turkish Journal of Agriculture and Forestry, Vol. 25, 169-173.

Gozlekci, S., Kaynak, L. (2000): Physical and chemical changes during fruit development and flowering in pomegranate (Punica granatum L.) cultivar Hicaznar grown in Antalya region, Production, processing and marketing of pomegranate in the Mediterranean region: Advances in research and technology, Zaragoza pg.79-85.

Mars, M. (2000): Pomegranate plant material: Genetic resources and breeding, a review. Options Méditerr, Sér A: SéminMéditerr, 42, 55-62.

Martinez, J.J., Melgarejo, P., Hernández, F. (2000): Study of the floral morphology of the pomegranate clones: PTO8, CRO1 and ME14, Conference paper, Options Mediterraneennes, 42, 105-113.

Melgarejo, P., Martinez-Valero, R., Guillamón, J.M., Miró, M., Amoros, A. (1997): Phenological stages of pomegranate tree (Punica granatum L.), Annals of Applieed Biology, Great Britain, 130, 135-140.

Nalawadi, U.G., Farooqui, A:A. Dasappa, M.A., Narayana Reddy, M.A., Gubbaiah, Sulikeri, G.S., Nalini, A.S. (1973): Studies on the floral biology of pomegranate (Punica granatum L.), Mysore Journal of Agricultural Science, 7, pg. 213-225, India. 
Zohary, D., Hopf, Maria (2000): Domestication of Plants in the Old World - The origin and spread of cultivated plants in West Asia, Europe and the Nile Valley, third edition, Oxford University Press Inc, New York.

Wetzstein, H.Y., Ravid, N., Wilkins, E., Martinelli, P. Adriana (2011): A morphological and histological characterization of bisexual and male flower types in pomegranate. Journal of the American Society for Horticultural Science, 136(2), 83-92. 